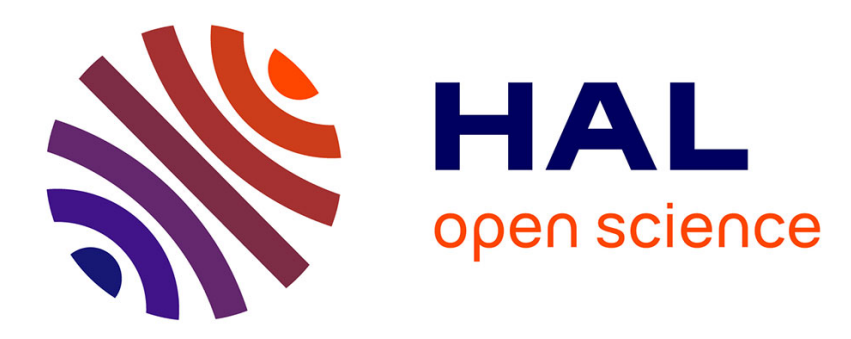

\title{
Global Imbalances and Capital Account Openness: an Empirical Analysis
}

\author{
Jamel Saadaoui
}

\section{To cite this version:}

Jamel Saadaoui. Global Imbalances and Capital Account Openness: an Empirical Analysis. 2011. halshs-00641456v2

\section{HAL Id: halshs-00641456 \\ https://shs.hal.science/halshs-00641456v2}

Preprint submitted on 21 Nov 2011

HAL is a multi-disciplinary open access archive for the deposit and dissemination of scientific research documents, whether they are published or not. The documents may come from teaching and research institutions in France or abroad, or from public or private research centers.
L'archive ouverte pluridisciplinaire HAL, est destinée au dépôt et à la diffusion de documents scientifiques de niveau recherche, publiés ou non, émanant des établissements d'enseignement et de recherche français ou étrangers, des laboratoires publics ou privés. 


\title{
CEPN Carterecteromente de l'Université Paris Nord CNRS UMR n ${ }^{\circ} 7234$

\author{
Document de travaild u C E P N No2011-18
}

\section{Global Imbalances and Capital Account Openness: an Empirical Analysis}

Jamel Saadaoui, University of Paris North, Center of Economics of Paris North

\begin{abstract}
We investigate if capital account openness has played a major role in the evolution of global imbalances on the period 1980-2003. We estimate, with panel regression techniques, the impact of capital account openness on medium run current account imbalances for industrialized and emerging countries by using a de jure measure of capital account openness (the Chinn-Ito index of capital account openness, 2002, 2006) and a de facto measure of capital account openness (the gross foreign assets measured as the sum of foreign assets and foreign liabilities). By increasing the opportunities of overseas investments, the relative capital account openness has had positive impact on medium run current account balances of industrialized countries (because of downward pressures on domestic investment rates). Conversely, the relative capital account openness has had negative impact on medium run current account balances of emerging countries (because of upward pressures on domestic investment rates). The evolutions of domestic and foreign capital account openness have allowed increasing medium run current account balances in absolute value during this period.
\end{abstract}

JEL Classification: F31, F41

Key words: Global Imbalances, Capital Account Openness, Chinn-Ito index 


\section{Introduction}

Current account imbalances have grown significantly the last fifteen years. Several factors have been designated, in the literature, as the main drivers of these imbalances: growth differentials, saving and investment rate differences, exchange rate misalignments and financial openness (i.e. capital account openness).

Since the middle of the 1990's, global imbalances intensify to reach a climax before the financial crisis in 2006-08. These evolutions can be considered as unsustainable and they have been one of the underlying causes of the financial crisis ${ }^{1}$. In 2006, the main contributors of these imbalances are the United States (with a deficit of more than 1.6 percent of world GDP), China and Asian countries and the oil exporters' countries (with a joint surplus of more than 1.8 percent of world GDP) as shown in figure 1.

Global imbalances are a threat to the global macroeconomic stability. Therefore identify the main causes and drivers of these imbalances seem to be crucial. We estimate, with panel regression techniques, the impact of capital account openness on medium run current account imbalances for industrialized and emerging countries by using a de jure measure of capital account openness (the Chinn-Ito index of capital account openness, 2002, 2006) and a de facto measure of capital account openness (the gross foreign assets measured as the sum of foreign assets and foreign liabilities). The main finding is that the relative capital account openness (measured relatively to world average) has played significant role on the magnitude of medium run current account. By increasing the opportunities of overseas investments, the relative financial openness has had positive impact on medium run current account balances of industrialized countries (because of downward pressures on domestic investment rates). Conversely, the relative financial openness has had negative impact on medium run current account balances of emerging countries (because of upward pressures on domestic investment rates).

For a number of industrialized countries, the evolution of the relative financial openness (which has dropped since the middle of the 1980's since they have already liberalized their capital account and that the world average has followed an increasing trend) has had a negative impact on medium run current account balances. For South-East Asian countries, the evolution of the relative financial openness (which has dropped since the middle of the 1980 's since these countries have liberalized their capital account more slowly than the world average) has had a positive impact on medium run current account balances.

\footnotetext{
${ }^{1}$ Servén and Nguyen (2010) examine the different views on the role of the global imbalances before and after the crisis.
} 
This paper is organized as follow. Section 2 presents various approaches which have been proposed to shed light on the development of global imbalances since the mid-1990's. Section 3 provides empirical results of the current account regressions. Section 4 studies in greater details the contributions of each explanatory variable to the medium run current account. Section 5 concludes.

Figure 1: Current account balances as percent of world GDP

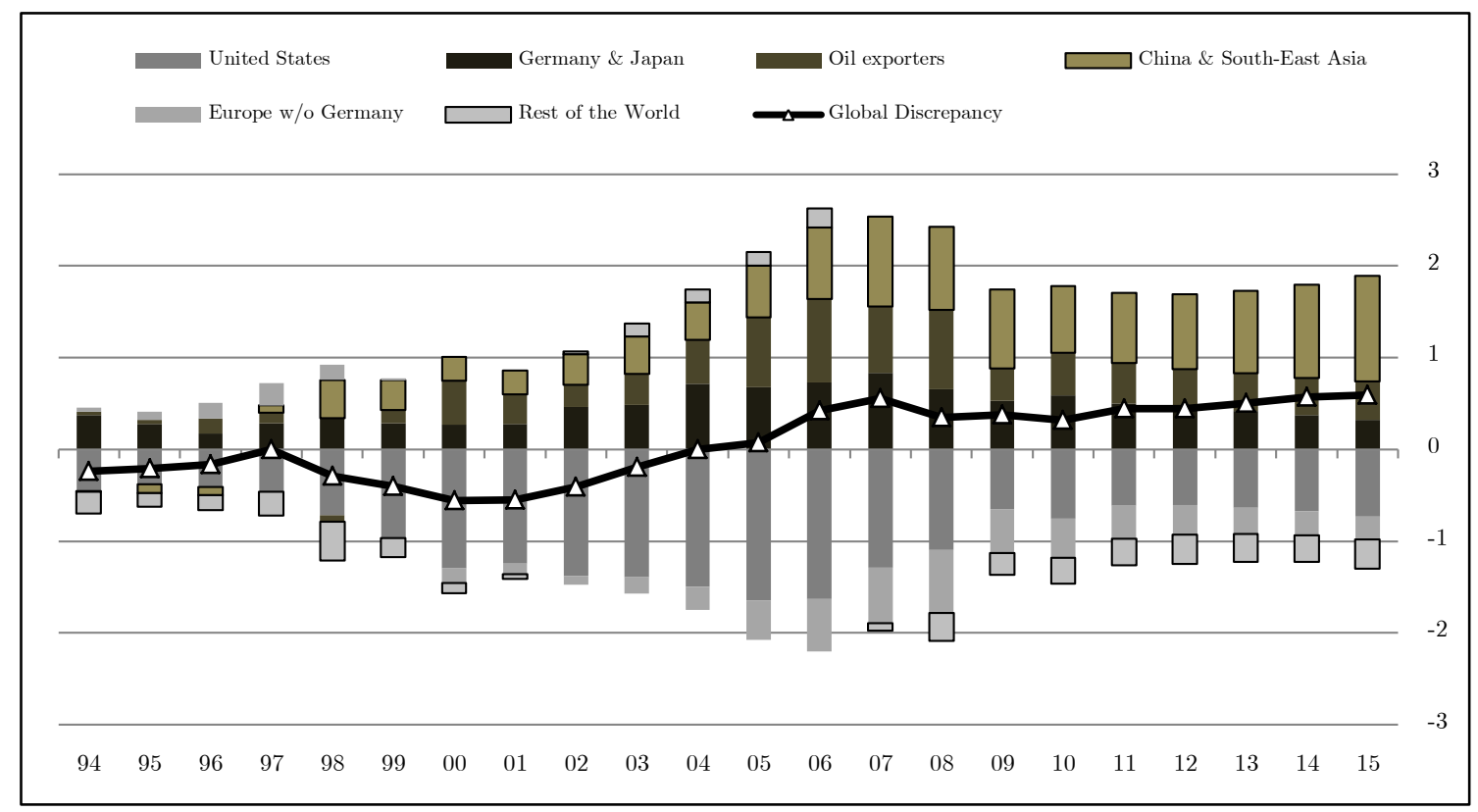

(Source: World Economic Outlook, October 2010, International Monetary Fund, forecast after 2009, author's calculations)

\section{Various explanatory approaches of global imbalances}

Various explanations have been proposed to explain the surge of global imbalances observed since the middle of the 1990's among them we find the Saving-Investment approach, the intertemporal approach, the Global Saving Glut hypothesis, Bretton-Woods II and East Asian Mercantilism versus Self-protection².

- The Saving-Investment approach

From the point of view of the national account identity, the external sector balance (the current account balance) can be seen as the sum of the public sector balance and the private sector balance:

${ }^{2}$ Chinn (2010) provides a large survey on these different approaches and the corresponding empirical findings. 
If we introduce the public receipts net of transfer payments in the equation [1], we obtained this new relationship (equation [2]):

$C A \equiv[T-G]+[S-I]$

With $Y$, gross domestic product; $C$, private consumption; $I$, private investment; $G$, government spending; $X$, Exports; $M$, Imports; $[S-I]$, private sector saving-investment balance, $C A$, current account balance.

The issues surrounding global imbalances can be analyzed as imbalances in domestic saving rates and domestic investment rates in the main economic areas at world scale. These imbalances could have been accentuated by financial openness (i.e. openness of the capital account) which has increased on the 1980-2003 period at the world level.

- $\quad$ The Intertemporal approach

The intertemporal approach is based on the behavior of rational expectation agent which maximizes utility function under a budget constraint. They smooth consumption by borrowing and saving thus current consumption is equal to a discounted value of future expected net output or net wealth. Change in expectations about future growth caused by productivity shocks or reductions in investment and government spending induces change in consumption.

In this perspective, the huge deficits observed in the U.S. during the 2000's could be interpreted as an expectation of a productivity boom which will improve future growth significantly. This view could be more attractive if the GDP growth has been driven by investment rather than by consumption during this period. It seems that the profit motive was not the main reason behind the huge incoming flows in the U. S.

- The Global Saving Glut hypothesis

Introduced by Bernanke (2005), Clarida (2005a, b), the "global saving glut" hypothesis explain the surge of U.S. deficit during the 2000's by a financial underdevelopment of Asian emerging countries. These differences in financial development and financial openness have allowed Asian emerging countries to export their excess of saving (due to rising savings and dropping investments after the 1997 crisis) to the U.S. Following the oil price evolutions, the 
oil exporter has become an important provider of savings to international financial markets. In this view, the U.S. external imbalance is a problem made overseas. The solution is to develop financial system of emerging market with excess saving in order to reduce the financial flow to countries with better financial system.

- Bretton-Woods II and East Asian Mercantilism versus Self-protection

The East Asian surpluses can be attributed to mercantilist behavior as an outcome of this concerted effort, the U.S. run large external have surged. Dooley, Folkerts-Landau, and Graber (2003, 2008) argue that financing of America's trade deficit is an explicit quid pro quo to continued access to American markets. The accumulation of large amount of reserve can be explained by a precautionary demand or self-insurance against volatility of capital flows and macroeconomic consequences of sudden drop for instance and notably after the East-Asian crisis of 1997.

\section{Empirical results}

As the current account equals the difference between domestic saving and investment (i.e. the saving-investment balance), the current account developments are examined from the perspective of the medium and long run determinants of saving and investment behaviors (Faruqee and Debelle, 1998, Chinn and Prasad, 2003). According to these authors, the main determinants of the current account at medium term are, inter alia, the demographic characteristics, such as, the dependency ratios of dependent populations relative to the working age population or the population growth, which is expected to exert a negative influence, with a higher dependency ratio leading to more spending; the government budget balance, with a public deficit having a negative effect on the current account, but this effect may be regarded as a simple accounting one which has not to be introduced ${ }^{3}$.

The equations of current account are estimated with panel data for 1980-2003 period and for two groups of countries. In a medium term perspective, we use non-overlapping four years average of annual data (Lee et al., 2008) ${ }^{4}$.

\footnotetext{
${ }^{3}$ There are other variables, such as the openness ratio, which plays negatively, a higher openness meaning a greater possibility of assuring the debt service in the future, or the relative real GDP per capita, which exerts a non-linear influence according to stages of development. The results were not significant enough. Moreover, relative GDP per capita is evaluated non stationary by most of tests.

${ }^{4}$ We introduce a panel GMM panel estimator in order to cope with eventual problems of endogeneity.
} 
$C A_{i, t}=S_{i, t}-I_{i, t}$

$C A_{i, t}=\alpha_{i}+\alpha_{t}+\beta_{0}+\beta_{1} R P G_{i, t}+\beta_{2} R O G_{i, t}+\beta_{3} R K A O P E N_{i, t}+\beta_{4} \Delta R G F A_{i, t}+\varepsilon_{i, t}$

The variables of equation [4] are defined as follows: $C A$, current account as \% of GDP; $R P G$, relative population growth (relative to the weighted world average), as percent of the total population; $R O G$, relative output gap (relative to the weighted world average) expressed as the percentage difference between actual GDP in constant prices, and estimated potential GDP; RKAOPEN, relative financial openness (relative to the weighted world average) based on the Chinn-Ito index; $R G F A$, relative gross foreign assets (relative to the weighted world average) in \% of GDP measured as the sum of foreign assets and foreign liabilities. The sources of the different variables are presented in appendix 1.

One group is composed of 18 industrial countries (Australia, Austria, Canada, Denmark, Finland, France, Germany, Ireland, Italy, Japan, Netherlands, New Zealand, Norway, Portugal, Spain, Sweden, the United Kingdom and the United States). The other group, composed of 21 emerging economies (Argentina, Brazil, Chile, China, Colombia, Ecuador, Egypt, India, Indonesia, Korea, Malaysia, Mexico, Morocco, Pakistan, Peru, Philippines, South Africa, Sri Lanka, Thailand, Tunisia and Turkey).

In the current account regressions for industrialized country group (table 1), the coefficients are significant and have the expected signs: the increase of the relative population growth $(R P G)$ reduces the current account balance (because of a higher proportion of dependent population), the increase of the relative output gap ( $R O G)$ deteriorates the current account (via the induced imports caused by the increase of the output gap of the country relatively to world average). For industrialized countries, an increase of relative financial openness (RKAOPEN or RGFA) allows to make investment abroad more extensively. Consequently, there is a downward pressure on the domestic investment rate and so, this evolution have a positive impact on the current account ${ }^{5}$.

The sign of this coefficient express the impact of a variation financial openness on the current account balance. This kind of relationship is connected with the extensive litterature on the capital account openness and economic growth nexus. If financial openness enhance growth then the current account deteriorates because of an increase of induced imports.

${ }^{5}$ In order to check this point, we replace in the regressions the current account balance by the domestic investment rate (see appendix 1 for the source of the data). We find that financial openness has a negative and statistically significant impact on the domestic investment rate for the industrialized countries group. 
However, the survey works on this issue by Eichengreen (2001) and by Kose et al. (2006) reports that the litterature failed to provide a robust and systematic (positive) evidence between growth and capital account openness.

As an illustration of this last point, two recent empirical studies (Carmignani, 2008, Quinn and Toyoda, 2008) found different results on this issue. Carmignani (2008) argues (thanks to a system estimation and a de jure measure of financial openness) that capital account openness stimulated growth through trade openness and financial development and that the direct effect of capital account on growth is negligeable. Quinn and Toyoda (2008) found empirical evidence of positive link between capital account openness and growth by using a de jure measure of capital account openness.

Table 1: Determinants of the current account for industrialized countries

\begin{tabular}{cccc}
\hline & OLS Pooled & OLS Individual & OLS Time \\
& Fixed Effects & Fixed Effects \\
\hline \multirow{2}{*}{ Constant } & $-2.54^{* * *}$ & $-1.43^{* * *}$ & $-2.45^{* * *}$ \\
& $(0.09)$ & $(0.21)$ & $(0.37)$ \\
$R P G$ & $-3.00^{* * *}$ & $-1.20^{* *}$ & $-3.03^{* * *}$ \\
& $(0.28)$ & $(0.51)$ & $(0.61)$ \\
ROG & $-0.37^{*}$ & $-0.48^{* * *}$ & $-0.39^{* * *}$ \\
RKAOPEN & $(0.19)$ & $(0.12)$ & $(0.14)$ \\
Adjusted $R$ squared & $1.08^{* * *}$ & $0.92^{* * *}$ & $0.92^{* * *}$ \\
Number of & $(0.15)$ & $(0.10)$ & $(0.25)$ \\
Observations & 0.40 & 0.77 & 0.36 \\
Hausman test statistic & 108 & 108 & 108 \\
\hline
\end{tabular}

Notes: The independent and dependent variables are non-overlapping 4-year averages of the corresponding annual variables. Heteroskedasticity robust standard errors are reported in parentheses. The symbols $*$, $* *$, and $* * *$ indicate statistical significance at the 10 percent, 5 percent, and 1 percent levels, respectively. The last row shows Hausman test statistics for random effects versus fixed effects specifications. P-values are reported in square brackets. Source: author's estimates.

Ordinary least square (OLS) specifications with individual fixed effects raise the coefficient of determination. The generalized method of moments panel estimator (Arellano and Bond, 1991; Arellano and Bover, 1995) shows that there is no problem of endogeneity for the chosen specification in the current account regressions for industrialized countries group (appendix $2)$. 
For a number of industrialized countries, the RKAOPEN variable follows a negative trend since the beginning of the 1980's. The RKAOPEN variable describes the magnitude of financial openness relative to global average of financial openness (which corresponds to a weighted average ${ }^{6}$ of the KAOPEN index (Chinn \& Ito, 2002, 2006).

Table 2: Panel unit root tests for industrialized countries

\begin{tabular}{cccccc}
\hline Variables & $C A$ & $R P G$ & $R O G$ & $R K A O P E N$ & $\Delta R G F A$ \\
\hline Industrialized countries group & $-11.01^{* * *}$ & $-19.49^{* * *}$ & $-51.20^{* * *}$ & $-28.83^{* * *}$ & $-2.50^{* * *}$ \\
& {$[0.00]$} & {$[0.00]$} & {$[0.00]$} & {$[0.00]$} & {$[0.00]$} \\
\hline
\end{tabular}

Notes: The symbols ${ }^{*},{ }^{*}$, and ${ }^{* * *}$ indicate statistical significance at the 10 percent, 5 percent, and 1 percent levels, respectively, using the test statistic Im Pesaran Shin; the rejection of the null hypothesis (of the presence of unit root), leads to reject non-stationarity of the series. P-values are reported in square brackets. Source: author's calculations.

Since the global average follows a positive trend since the middle of the 1980's and that many industrialized countries have already liberalized their capital account in early 1980's, the relative capital openness variable (RKAOPEN) dropped in these countries. These evolutions have contributed negatively to the current account since the estimated coefficient is positive and statistically significant for the industrialized countries' panel in all regressions (see appendix 3, for the linear correlation between current account and RKAOPEN).

In order to check the consistency of the results, we introduce an alternative measure of financial openness $(R G F A)$ which corresponds to the sum of the foreign assets and foreign liabilities of the country relatively to world average in \% of GDP. The coefficient of the $R G F A$ variable $^{7}$ is positive and statistically significant for the industrialized country like in regression with the RKAOPEN variable. This is reassuring about the robustness of the results (see appendix 4).

\footnotetext{
${ }^{6}$ The weights are equals to the share of each country in world GDP in dollar PPP terms. More precisely, the more the KAOPEN index is high, the more the country is open to cross-border capital transactions. In order to avoid the complexity of interpreting the estimated coefficients, this variable (KAOPEN) is adjusted such that the minimum value is zero, i.e., they range between zero and some positive value. The demeaning of the series allows controlling for rest of the world effects (Chinn \& Ito, 2007).

${ }^{7}$ The $R G F A$ variable is not stationary in level so we use the variation, to avoid fallacious regressions' problems, of this variable but the interpretation remains basically the same than for the RKAOPEN variable.
} 
Table 3: Determinants of the current account for emerging countries

\begin{tabular}{cccc}
\hline & OLS Pooled & OLS Individual & OLS Time \\
& Fixed Effects & Fixed Effects \\
\hline \multirow{2}{*}{ Constant } & $-0.97^{* *}$ & -0.30 & $-1.19^{* *}$ \\
& $(0.40)$ & $(0.50)$ & $(0.52)$ \\
RPG & $-1.94^{* * *}$ & $-3.21^{* * *}$ & $-1.66^{* * *}$ \\
& $(0.36)$ & $(0.41)$ & $(0.43)$ \\
ROG & $-0.44^{* * *}$ & $-0.35^{* * *}$ & $-0.33^{* * *}$ \\
RKAOPEN & $(0.06)$ & $(0.06)$ & $(0.10)$ \\
Adjusted $R$ squared & $-0.47^{* *}$ & $-0.63^{* *}$ & $-0.45^{*}$ \\
Number of & $(0.17)$ & $(0.23)$ & $(0.18)$ \\
Observations & 0.47 & 0.68 & 0.35 \\
Hausman test statistic & 126 & & 126 \\
\hline
\end{tabular}

Notes: The independent and dependent variables are non-overlapping 4-year averages of the corresponding annual variables. Heteroskedasticity robust standard errors are reported in parentheses. The symbols *, **, and *** indicate statistical significance at the 10 percent, 5 percent, and 1 percent levels, respectively. The last row shows Hausman test statistics for random effects versus fixed effects specifications. P-values are reported in square brackets. Source: author's estimates.

Table 4: Panel unit root tests for emerging countries

\begin{tabular}{cccccc}
\hline Variables & $C A$ & $R P G$ & $R O G$ & $R K A O P E N$ & $\Delta R G F A$ \\
\hline Emerging countries group & $-5.88^{* * *}$ & $-6.19^{* * *}$ & $-27.17^{* * *}$ & $-4.74^{* * *}$ & $-4.74^{* * *}$ \\
& {$[0.00]$} & {$[0.00]$} & {$[0.00]$} & {$[0.00]$} & {$[0.00]$} \\
\hline
\end{tabular}

Notes: The symbols ${ }^{*},{ }^{*}$, and ${ }^{* * *}$ indicate statistical significance at the 10 percent, 5 percent, and 1 percent levels, respectively, using the test statistic Im Pesaran Shin; the rejection of the null hypothesis (of the presence of unit root), leads to reject non-stationarity of the series. P-values are reported in square brackets. Source: author's calculations.

The results of unit root tests are presented in table 2 and 4 . As it can be seen, the null hypothesis of non-stationarity is rejected in all the series.

In the current account regressions for emerging country group (table 3), the coefficients are significant and have the expected signs. Once again, OLS specifications with individual fixed effects raise the coefficient of determination. GMM panel estimator shows that there is no 
problem of endogeneity for the chosen specification in the current account regressions (appendix 2). The main difference with the current account regression for industrialized countries group is the sign of the coefficient of the RKAOPEN variable which is negative for emerging countries group (see appendix 3 for the linear correlation between current account and RKAOPEN).

For emerging countries, an increase of relative financial openness (RKAOPEN or RGFA) allows to receive investments from abroad more extensively. Consequently, there is an upward pressure on the domestic investment rate $^{8}$ and so, this evolution have a negative impact on the current account (Ito \& Chinn, 2007).

Once again, the de facto measure of financial openness $(R G F A)$ is statistically significant and has the same sign (i.e. negative) than that of the RKAOPEN variable for the emerging countries group (see appendix 4).

For a number of emerging countries, the RKAOPEN variable follows a negative trend since the beginning of the 1980's. The RKAOPEN variable describes the magnitude of financial openness relative to global average of financial openness (which corresponds to a weighted average $^{9}$ of the KAOPEN index (Chinn \& Ito, 2002, 2006)).

For these countries, the drop of the relative capital openness (RKAOPEN) variable means that they liberalized their capital account more slowly than the global average. These evolutions have contributed positively to the current account since the estimated coefficient is negative and statistically significant for the emerging countries' panel in all regressions.

\footnotetext{
${ }^{8}$ In order to check this point, we replace in the regressions the current account balance by the domestic investment rate (see appendix 1 for the source of the data). We find that financial openness has a positive and statistically significant impact on the domestic investment rate for the emerging countries group.

${ }^{9}$ See note 4 .
} 


\section{Contributions to the medium run current account balances}

As it been explained in the previous section, the drop of the RKAOPEN variable has induced an increase of the medium run deficit in a number of industrialized countries and an increase of the medium run surplus of South-East Asia's emerging countries. This section illustrates this point by studying some striking cases.

\section{- $\quad$ The United States and the United Kingdom}

The case of the United Stated (table 5 to 10) is very interesting because it illustrates very well the case of countries which have totally liberalized its capital account in the early 1980's (thus the KAOPEN index, which is an inverse measure of capital controls, reached its upper limit). In addition, the global average of financial openness had increase on the 1980-2003's period (see appendix 5). These two evolutions have induced a drop of the RKAOPEN variable for the United States. The medium run current account ${ }^{10}$, which was around - $1.7 \%$ at the beginning of the 1980's, have reached around $-2.5 \%$ at the beginning of the 2000's. In this evolution, the relative financial openness has played a negative role. In fact, the contribution of the RKAOPEN variable was near from $1.3 \%$ in the beginning of the period was reduced to only $0.9 \%$ because the domestic and foreign evolution of the financial openness which have been already describe and because of positive coefficients of the $R K A O P E N$ variable in the current account regressions for industrialized countries.

The case of the United Kingdom (table 5 to 10) is very similar to that of the United States, in a smaller scale. However, the capital account was totally liberalized only at the middle of the 1980's. The medium run current account have dropped to $-1.7 \%$ at the end of the period whereas it was equal to $-1 \%$ in 1980 . Once again the reduction of the relative capital openness (the RKAOPEN variable) has played a negative role in the evolution of the medium run current account from the middle of the 1980's to the end of the period.

- South-East Asian countries and India

For South-East Asian's emerging countries, the story is completely different. These countries have also seen the RKAOPEN variable decrease but for different reasons of those of the United States or the United Kingdom. The main explanation of this drop is that, globally,

\footnotetext{
${ }^{10}$ We use the OLS individual fixed effects specification to calculate the medium-term current account (i.e. equilibrium current account) for all the countries. In order to capture medium to long run trends, we set the output gaps at zero.
} 
East Asian's emerging countries have opened they capital account more slowly than the world average (see appendix 5). For China (table 5 to 10), the medium-term current account have grown significantly from the beginning of the period (from 1\% in 1980 to $2.5 \%$ in 2003) in this evolution the reduction of the relative population growth and the stability of the financial openness have played a positive role $^{11}$.

The cases of Malaysia and Indonesia (table 5 to 10) are similar on several points. They have increased their medium run current account since the beginning of the 1980's (from around $2 \%$ in 1980 to $1 \%$ in 2003 for Indonesia; from $0 \%$ to $2 \%$ for Malaysia). In these evolutions the reduction of the relative population growth and the drop of the relative financial openness (due to the fact that these countries have liberalized their capital account more slowly than the world average) have played a positive role.

The medium run current accounts of Thailand and the Philippines have different profiles (table 5 to 10) but, in these two countries, the stability of the relative financial openness has had a positive impact on the underlying capital flows, on the whole period. The medium run current account, which was very negative in the beginning of the sample $(-4 \%$ for Thailand and $-2.5 \%$ for the Philippines), have progressively improved to reach $0 \%$ in Thailand and $2 \%$ in the Philippines. In this evolution, the depletion of the population growth has played a positive role.

The evolution of the relative financial openness in the South-East Asian's emerging countries reflect the fact these countries have liberalized their capital account more slowly than the world average. This relative decrease has had a positive impact on the current for these countries since the coefficient associated to the RKAOPEN variable is negative for the emerging countries group.

The evolutions of the medium run current account of India and its contributions (table 5 to 10) can be compared to those of South-East Asian's emerging countries. Insofar the medium run current account has improved steadily during the whole period (from around $-2 \%$ to around $0 \%$ ). In addition, the stability of relative financial openness has contributed positively (about 1\%) to the medium run current account and the reduction of the dependency ratio has also had a positive impact but to a lesser extent than small South-East Asian countries

\footnotetext{
${ }^{11}$ It seems to be important to recall that the signs of the coefficients are negative and statistically significant for the RKAOPEN variable in all current account regression of the emerging countries group.
} 
which are submitted to weaker demographic constrained (comparatively to demographic giants like China and India $\left.{ }^{12}\right)$.

- Latin American countries

The case of Latin American countries is more dispersed than those of South-East Asian countries on the 1980-2003's period. For Brazil (table 5 to 10), the evolution of the relative financial openness has had a positive impact until the end of the 2000's. At the beginning of the 2000, Brazil opened his capital account more rapidly (see appendix 5) and this evolution induced a drop in the positive contribution of relative financial openness observed earlier. In spite of this decreasing evolution of financial openness, the reduction of the population growth has had a positive impact on the medium run current account which has slowly improved (from $-4 \%$ to $-2 \%$ ).

The case of Mexico (table 5 to 10) can be seen as the opposite of South-East Asian's emerging countries cases. Indeed, Mexico had strongly reduced its relative capital openness (see appendix 5) after the debt crisis. The RKAOPEN variable decreased until 1986 and after that the openness index increased steadily until the beginning of the 2000's. This evolution of relative financial openness has contributed negatively to the medium run current account from the middle of the 1980's to the beginning of the 2000's. In spite of this negative contribution of financial openness, the medium run current account has improved strongly (from around $-4 \%$ to around $0 \%$ ) mainly thanks to favorable demographic evolution.

Argentina is the country in which the medium-term current account has known the most contrasted movements (table 5 to 10) mainly due to large variation in the relative financial openness. The medium run current account has improved on the whole period (from $-1.5 \%$ to $-0.5 \%$ ) but with large variations notably during the period of the currency board system. At the beginning of the currency board scheme, the relative financial openness has been more pronounced and, thus, the contribution of the RKAOPEN variable which has been positive (around 1\%) in 1988-1991, became negative (around -0.3\%) in 1996-1999. This evolution of the relative financial openness has participated to accentuate the current account deficit during the currency board era. After the burst of the crisis in 2001, the medium run current account became less negative (about $-0.5 \%$ ).

\footnotetext{
${ }^{12}$ In spite of similar demographic profiles, China and India have had different policy of fertility. The 'one-child policy' has allowed an impressive reduction of the population growth and dependency ratios in China.
} 
For Chile, the medium run current account remains stable to around $-4 \%$ (table 5 to 10 ). The relative financial openness is relatively stable and contributed positively to the medium term current account until the beginning of the 2000's. At this moment, Chile has opened its capital account more rapidly ${ }^{13}$ and so the contribution to the medium run current account of the RKAOPEN variable decreased sharply.

For Colombia, the medium-term current account has steadily improved from $-2 \%$ to $-1 \%$ on the whole period (table 5 to 10 ). The stability of the relative financial openness has contributed positively (like in the case of South-East Asian's emerging countries) to the medium run current account. An impressive reduction of the relative population growth has, also, contributed to the medium run current account progression.

\footnotetext{
${ }^{13}$ Interestingly, Brazil and Chile have opened more rapidly their capital account at the beginning of the 2000's whereas Argentina has known the inverse evolution.
} 
Table 5: Contribution to the medium run current account on the 1980-1983 period (in \% of GDP)

\begin{tabular}{|c|c|c|c|c|c|c|}
\hline & $\begin{array}{l}\text { Actual } \\
\text { current } \\
\text { account }\end{array}$ & $\begin{array}{c}\text { Medium run } \\
\text { current } \\
\text { account }\end{array}$ & $\begin{array}{c}\text { Population } \\
\text { Growth }\end{array}$ & Kaopen & Intercept & $\begin{array}{l}\text { Individual } \\
\text { fixed effect }\end{array}$ \\
\hline & {$[1]$} & {$[2]$} & {$[3]$} & {$[4]$} & {$[5]$} & {$[6]$} \\
\hline \multicolumn{7}{|l|}{ Industrial } \\
\hline United States & -0.26 & -1.77 & 0.06 & 1.33 & -1.44 & -1.73 \\
\hline Japan & 0.45 & 2.07 & 0.34 & 0.96 & -1.44 & 2.20 \\
\hline Germany & -0.28 & 0.94 & 1.20 & 1.33 & -1.44 & -0.16 \\
\hline France & -1.09 & -0.60 & 0.59 & -1.34 & -1.44 & 1.59 \\
\hline United Kingdom & 0.96 & -1.08 & 1.17 & 0.96 & -1.44 & -1.76 \\
\hline Italy & -2.38 & -2.14 & 1.08 & -1.90 & -1.44 & 0.11 \\
\hline Canada & -1.65 & -1.39 & -0.22 & 1.33 & -1.44 & -1.07 \\
\hline \multicolumn{7}{|l|}{ Developing } \\
\hline China & 1.06 & 0.79 & -1.16 & 1.74 & -0.30 & 0.52 \\
\hline Brazil & -6.65 & -3.64 & -4.23 & 1.84 & -0.30 & -0.95 \\
\hline India & -1.54 & -1.91 & -3.88 & 1.41 & -0.30 & 0.86 \\
\hline Mexico & -2.64 & -4.21 & -4.26 & 0.17 & -0.30 & 0.20 \\
\hline Korea & -4.97 & -1.05 & -1.71 & 1.08 & -0.30 & -0.12 \\
\hline Indonesia & -2.31 & -1.96 & -3.54 & -0.51 & -0.30 & 2.39 \\
\hline Argentina & -2.60 & -1.62 & -1.64 & 1.08 & -0.30 & -0.75 \\
\hline Thailand & -5.92 & -3.48 & -2.46 & 0.75 & -0.30 & -1.47 \\
\hline Colombia & -3.72 & -2.40 & -3.82 & 1.84 & -0.30 & -0.12 \\
\hline Malaysia & -8.89 & -0.33 & -4.79 & -0.51 & -0.30 & 5.28 \\
\hline Chile & -8.99 & -4.14 & -1.70 & 1.30 & -0.30 & -3.44 \\
\hline Philippines & -5.51 & -2.49 & -4.80 & 1.41 & -0.30 & 1.21 \\
\hline
\end{tabular}

Note: The independent and dependent variables are non-overlapping 4-year averages of the corresponding annual variables. Source: author's calculations. 
Table 6: Contribution to the medium run current account on the 1984-1987 period (in \% of GDP)

\begin{tabular}{|c|c|c|c|c|c|c|}
\hline & $\begin{array}{l}\text { Actual } \\
\text { current } \\
\text { account }\end{array}$ & $\begin{array}{c}\text { Medium run } \\
\text { current } \\
\text { account }\end{array}$ & $\begin{array}{c}\text { Population } \\
\text { Growth }\end{array}$ & Kaopen & Intercept & $\begin{array}{l}\text { Individual } \\
\text { fixed effect }\end{array}$ \\
\hline & {$[1]$} & {$[2]$} & {$[3]$} & {$[4]$} & {$[5]$} & {$[6]$} \\
\hline \multicolumn{7}{|l|}{ Industrial } \\
\hline United States & -2.97 & -1.88 & 0.03 & 1.26 & -1.44 & -1.73 \\
\hline Japan & 3.58 & 2.43 & 0.40 & 1.26 & -1.44 & 2.20 \\
\hline Germany & 3.05 & 0.88 & 1.22 & 1.26 & -1.44 & -0.16 \\
\hline France & -0.10 & -0.40 & 0.62 & -1.17 & -1.44 & 1.59 \\
\hline United Kingdom & -0.80 & -1.09 & 0.86 & 1.26 & -1.44 & -1.76 \\
\hline Italy & -0.54 & -1.41 & 1.09 & -1.17 & -1.44 & 0.11 \\
\hline Canada & -2.05 & -1.41 & -0.16 & 1.26 & -1.44 & -1.07 \\
\hline \multicolumn{7}{|l|}{ Developing } \\
\hline China & -1.37 & 0.10 & -1.68 & 1.57 & -0.30 & 0.52 \\
\hline Brazil & -0.61 & -3.11 & -3.75 & 1.90 & -0.30 & -0.95 \\
\hline India & -1.75 & -1.81 & -3.83 & 1.46 & -0.30 & 0.86 \\
\hline Mexico & 1.13 & -2.18 & -3.67 & 1.60 & -0.30 & 0.20 \\
\hline Korea & 2.30 & 0.71 & -0.33 & 1.46 & -0.30 & -0.12 \\
\hline Indonesia & -2.93 & -1.97 & -3.20 & -0.86 & -0.30 & 2.39 \\
\hline Argentina & -2.45 & -1.43 & -1.84 & 1.46 & -0.30 & -0.75 \\
\hline Thailand & -2.29 & -2.72 & -1.75 & 0.80 & -0.30 & -1.47 \\
\hline Colombia & -1.64 & -2.23 & -3.70 & 1.90 & -0.30 & -0.12 \\
\hline Malaysia & 0.25 & -1.95 & -6.07 & -0.86 & -0.30 & 5.28 \\
\hline Chile & -7.45 & -4.22 & -2.38 & 1.90 & -0.30 & -3.44 \\
\hline Philippines & 1.46 & -2.59 & -4.79 & 1.30 & -0.30 & 1.21 \\
\hline
\end{tabular}

Note: The independent and dependent variables are non-overlapping 4-year averages of the corresponding annual variables. Source: author's calculations. 
Table 7: Contribution to the medium run current account on the 1988-1991 period (in \% of GDP)

\begin{tabular}{|c|c|c|c|c|c|c|}
\hline & $\begin{array}{l}\text { Actual } \\
\text { current } \\
\text { account }\end{array}$ & $\begin{array}{c}\text { Medium run } \\
\text { current } \\
\text { account }\end{array}$ & $\begin{array}{c}\text { Population } \\
\text { Growth }\end{array}$ & Kaopen & Intercept & $\begin{array}{l}\text { Individual } \\
\text { fixed effect }\end{array}$ \\
\hline & {$[1]$} & {$[2]$} & {$[3]$} & {$[4]$} & {$[5]$} & {$[6]$} \\
\hline \multicolumn{7}{|l|}{ Industrial } \\
\hline United States & -1.38 & -2.05 & -0.09 & 1.20 & -1.44 & -1.73 \\
\hline Japan & 2.07 & 2.74 & 0.77 & 1.20 & -1.44 & 2.20 \\
\hline Germany & 2.57 & -0.01 & 0.39 & 1.20 & -1.44 & -0.16 \\
\hline France & -0.55 & -0.39 & 0.49 & -1.04 & -1.44 & 1.59 \\
\hline United Kingdom & -3.63 & -1.11 & 0.89 & 1.20 & -1.44 & -1.76 \\
\hline Italy & -1.76 & -1.23 & 1.13 & -1.04 & -1.44 & 0.11 \\
\hline Canada & -3.51 & -1.88 & -0.57 & 1.20 & -1.44 & -1.07 \\
\hline \multicolumn{7}{|l|}{ Developing } \\
\hline China & 1.10 & 0.58 & -1.56 & 1.94 & -0.30 & 0.52 \\
\hline Brazil & 0.08 & -1.74 & -2.42 & 1.94 & -0.30 & -0.95 \\
\hline India & -2.29 & -1.26 & -3.32 & 1.50 & -0.30 & 0.86 \\
\hline Mexico & -2.85 & -1.84 & -2.89 & 1.16 & -0.30 & 0.20 \\
\hline Korea & 1.64 & 0.45 & 0.03 & 0.84 & -0.30 & -0.12 \\
\hline Indonesia & -2.34 & -0.93 & -2.20 & -0.82 & -0.30 & 2.39 \\
\hline Argentina & 0.80 & -0.88 & -1.33 & 1.50 & -0.30 & -0.75 \\
\hline Thailand & -5.49 & -1.72 & -0.79 & 0.84 & -0.30 & -1.47 \\
\hline Colombia & 1.14 & -1.74 & -3.03 & 1.72 & -0.30 & -0.12 \\
\hline Malaysia & -1.20 & -1.70 & -5.86 & -0.82 & -0.30 & 5.28 \\
\hline Chile & -1.29 & -4.19 & -2.38 & 1.94 & -0.30 & -3.44 \\
\hline Philippines & -2.69 & -1.97 & -4.38 & 1.50 & -0.30 & 1.21 \\
\hline
\end{tabular}

Note: The independent and dependent variables are non-overlapping 4-year averages of the corresponding annual variables. Source: author's calculations. 
Table 8: Contribution to the medium run current account on the 1992-1995 period (in \% of GDP)

\begin{tabular}{|c|c|c|c|c|c|c|}
\hline & $\begin{array}{l}\text { Actual } \\
\text { current } \\
\text { account }\end{array}$ & $\begin{array}{c}\text { Medium run } \\
\text { current } \\
\text { account }\end{array}$ & $\begin{array}{c}\text { Population } \\
\text { Growth }\end{array}$ & Kaopen & Intercept & $\begin{array}{l}\text { Individual } \\
\text { fixed effect }\end{array}$ \\
\hline & {$[1]$} & {$[2]$} & {$[3]$} & {$[4]$} & {$[5]$} & {$[6]$} \\
\hline \multicolumn{7}{|l|}{ Industrial } \\
\hline United States & -1.33 & -2.59 & -0.35 & 0.92 & -1.44 & -1.73 \\
\hline Japan & 2.72 & 2.46 & 0.83 & 0.86 & -1.44 & 2.20 \\
\hline Germany & -1.16 & -0.09 & 0.59 & 0.92 & -1.44 & -0.16 \\
\hline France & 0.50 & 1.33 & 0.74 & 0.44 & -1.44 & 1.59 \\
\hline United Kingdom & -1.55 & -1.39 & 0.88 & 0.92 & -1.44 & -1.76 \\
\hline Italy & 0.46 & 0.27 & 1.15 & 0.44 & -1.44 & 0.11 \\
\hline Canada & -2.63 & -1.63 & -0.05 & 0.92 & -1.44 & -1.07 \\
\hline \multicolumn{7}{|l|}{ Developing } \\
\hline China & 0.24 & 1.50 & -0.51 & 1.80 & -0.30 & 0.52 \\
\hline Brazil & -0.34 & -0.88 & -1.75 & 2.13 & -0.30 & -0.95 \\
\hline India & -0.97 & -0.44 & -2.69 & 1.69 & -0.30 & 0.86 \\
\hline Mexico & -4.73 & -2.31 & -2.63 & 0.43 & -0.30 & 0.20 \\
\hline Korea & -0.91 & 0.47 & -0.14 & 1.03 & -0.30 & -0.12 \\
\hline Indonesia & -1.98 & -0.22 & -1.68 & -0.63 & -0.30 & 2.39 \\
\hline Argentina & -3.12 & -1.80 & -1.08 & 0.33 & -0.30 & -0.75 \\
\hline Thailand & -5.95 & -1.24 & -0.50 & 1.03 & -0.30 & -1.47 \\
\hline Colombia & -2.53 & -1.14 & -2.73 & 2.02 & -0.30 & -0.12 \\
\hline Malaysia & -6.31 & -0.07 & -5.02 & -0.03 & -0.30 & 5.28 \\
\hline Chile & -3.07 & -4.45 & -2.46 & 1.76 & -0.30 & -3.44 \\
\hline Philippines & -3.61 & -2.45 & -4.07 & 0.72 & -0.30 & 1.21 \\
\hline
\end{tabular}

Note: The independent and dependent variables are non-overlapping 4-year averages of the corresponding annual variables. Source: author's calculations. 
Table 9: Contribution to the medium run current account on the 1996-1999 period (in \% of GDP)

\begin{tabular}{|c|c|c|c|c|c|c|}
\hline & $\begin{array}{l}\text { Actual } \\
\text { current } \\
\text { account }\end{array}$ & $\begin{array}{c}\text { Medium run } \\
\text { current } \\
\text { account }\end{array}$ & $\begin{array}{c}\text { Population } \\
\text { Growth }\end{array}$ & Kaopen & Intercept & $\begin{array}{l}\text { Individual } \\
\text { fixed effect }\end{array}$ \\
\hline & {$[1]$} & {$[2]$} & {$[3]$} & {$[4]$} & {$[5]$} & {$[6]$} \\
\hline \multicolumn{7}{|l|}{ Industrial } \\
\hline United States & -2.24 & -2.57 & -0.32 & 0.92 & -1.44 & -1.73 \\
\hline Japan & 2.34 & 2.24 & 0.80 & 0.67 & -1.44 & 2.20 \\
\hline Germany & -0.76 & 0.25 & 0.93 & 0.92 & -1.44 & -0.16 \\
\hline France & 2.41 & 1.76 & 0.69 & 0.92 & -1.44 & 1.59 \\
\hline United Kingdom & -0.91 & -1.53 & 0.75 & 0.92 & -1.44 & -1.76 \\
\hline Italy & 2.08 & 0.65 & 1.05 & 0.92 & -1.44 & 0.11 \\
\hline Canada & -0.43 & -1.65 & -0.07 & 0.92 & -1.44 & -1.07 \\
\hline \multicolumn{7}{|l|}{ Developing } \\
\hline China & 2.31 & 1.61 & -0.29 & 1.69 & -0.30 & 0.52 \\
\hline Brazil & -3.64 & -1.27 & -1.93 & 1.91 & -0.30 & -0.95 \\
\hline India & -1.20 & -0.42 & -2.67 & 1.69 & -0.30 & 0.86 \\
\hline Mexico & -2.16 & -1.64 & -1.76 & 0.23 & -0.30 & 0.20 \\
\hline Korea & 2.84 & 1.50 & 0.23 & 1.69 & -0.30 & -0.12 \\
\hline Indonesia & 0.75 & 0.40 & -1.59 & -0.09 & -0.30 & 2.39 \\
\hline Argentina & -3.91 & -2.21 & -0.86 & -0.29 & -0.30 & -0.75 \\
\hline Thailand & 3.25 & -1.35 & -0.61 & 1.03 & -0.30 & -1.47 \\
\hline Colombia & -3.18 & -1.40 & -2.67 & 1.69 & -0.30 & -0.12 \\
\hline Malaysia & 4.62 & 0.46 & -5.12 & 0.60 & -0.30 & 5.28 \\
\hline Chile & -3.32 & -3.32 & -1.59 & 2.02 & -0.30 & -3.44 \\
\hline Philippines & -2.81 & -2.10 & -3.89 & 0.89 & -0.30 & 1.21 \\
\hline
\end{tabular}

Note: The independent and dependent variables are non-overlapping 4-year averages of the corresponding annual variables. Source: author's calculations. 
Table 10: Contribution to the medium run current account on the 2000-2003 period (in \% of GDP)

\begin{tabular}{|c|c|c|c|c|c|c|}
\hline & $\begin{array}{l}\text { Actual } \\
\text { current } \\
\text { account }\end{array}$ & $\begin{array}{c}\text { Medium run } \\
\text { current } \\
\text { account }\end{array}$ & $\begin{array}{c}\text { Population } \\
\text { Growth }\end{array}$ & Kaopen & Intercept & $\begin{array}{l}\text { Individual } \\
\text { fixed effect }\end{array}$ \\
\hline & {$[1]$} & {$[2]$} & {$[3]$} & {$[4]$} & {$[5]$} & {$[6]$} \\
\hline \multicolumn{7}{|l|}{ Industrial } \\
\hline United States & -4.30 & -2.45 & -0.21 & 0.92 & -1.44 & -1.73 \\
\hline Japan & 2.70 & 2.47 & 0.78 & 0.92 & -1.44 & 2.20 \\
\hline Germany & 0.59 & 0.20 & 0.87 & 0.92 & -1.44 & -0.16 \\
\hline France & 1.44 & 1.33 & 0.26 & 0.92 & -1.44 & 1.59 \\
\hline United Kingdom & -2.01 & -1.69 & 0.58 & 0.92 & -1.44 & -1.76 \\
\hline Italy & -0.67 & 0.28 & 0.68 & 0.92 & -1.44 & 0.11 \\
\hline Canada & 1.98 & -1.64 & -0.06 & 0.92 & -1.44 & -1.07 \\
\hline \multicolumn{7}{|l|}{ Developing } \\
\hline China & 2.06 & 2.48 & 0.57 & 1.69 & -0.30 & 0.52 \\
\hline Brazil & -2.18 & -1.89 & -1.86 & 1.23 & -0.30 & -0.95 \\
\hline India & 0.56 & -0.25 & -2.34 & 1.53 & -0.30 & 0.86 \\
\hline Mexico & -2.21 & -0.40 & -0.85 & 0.56 & -0.30 & 0.20 \\
\hline Korea & 1.75 & 1.44 & 0.67 & 1.20 & -0.30 & -0.12 \\
\hline Indonesia & 4.14 & 0.77 & -1.54 & 0.23 & -0.30 & 2.39 \\
\hline Argentina & 2.67 & -0.50 & -0.48 & 1.03 & -0.30 & -0.75 \\
\hline Thailand & 4.77 & -0.65 & 0.09 & 1.03 & -0.30 & -1.47 \\
\hline Colombia & -0.72 & -1.04 & -2.31 & 1.69 & -0.30 & -0.12 \\
\hline Malaysia & 9.21 & 2.07 & -3.94 & 1.03 & -0.30 & 5.28 \\
\hline Chile & -1.18 & -4.40 & -0.99 & 0.34 & -0.30 & -3.44 \\
\hline Philippines & -1.35 & -2.20 & -3.99 & 0.89 & -0.30 & 1.21 \\
\hline
\end{tabular}

Note: The independent and dependent variables are non-overlapping 4-year averages of the corresponding annual variables. Source: author's calculations. 


\section{Conclusion}

Global imbalances are a threat to the global macroeconomic stability. Therefore identify the main causes and drivers of these imbalances seem to be crucial. The objective of this paper was to investigate if financial openness has played a major role in the evolution of global imbalances on the period 1980-2003.

The main finding is that the relative financial openness (measured as the deviation relatively to world average) has played significant role on the magnitude of medium run current account. By increasing the opportunities of overseas investments, the relative financial openness has had positive impact on medium run current account of industrialized countries (because of downward pressures on domestic investment rates). Conversely, the relative financial openness has had negative impact on medium run current account of emerging countries (because of upward pressures on domestic investment rates). For a number of industrialized countries, the relative financial openness has had a negative impact on medium run current account. For South-East Asian countries, the relative financial openness has had a positive impact on medium run current account. The evolution of domestic and foreign financial openness has allowed increasing the medium run current account in absolute value.

In the recent debate on the ceiling of the current account surplus (The Economist, 2010), many observers have raised questions on how quantify the threshold from which world macroeconomic stability is assured. We argue that financial openness should be taken in account in these kinds of calculations. The evolution of domestic and foreign financial openness has allowed increasing the medium run current account in absolute value during the period 1980-2003. 


\section{Appendix 1}

Table A1.1: Sources of the data

\begin{tabular}{llll}
\hline Variable & Description & Unit & Source \\
\hline
\end{tabular}

Current account is all transactions other than those in financial and capital items. The major classifications are goods and services, income

CA and current transfers. The focus of the BOP is

Percent of GDP on transactions (between an economy and the rest of the world) in goods, services, and income.

GFA The sum of foreign asset and foreign liabillities.

Percent of GDP

Gross capital formation (formerly gross domestic investment) consists of outlays on additions to the fixed assets of the economy plus net changes in the level of inventories. Fixed assets include land improvements (fences, ditches, drains, and so on); plant, machinery, and equipment purchases; and the construction of roads,

INV railways, and the like, including schools, offices, hospitals, private residential dwellings, and commercial and industrial buildings. Inventories are stocks of goods held by firms to meet temporary or unexpected fluctuations in production or sales, and "work in progress." According to the 1993 SNA, net acquisitions of valuables are also considered capital formation.

The first standardized principal component of

KAOPEN $\mathrm{k}_{1 \mathrm{t}}, \mathrm{k}_{2 \mathrm{t}}, \mathrm{SHAREk}_{3 \mathrm{t}}, \mathrm{k}_{4 \mathrm{t}}$ (See appendix 5).

The output gap is measured as the percentage difference between actual GDP in constant prices, and estimated potential GDP. The latter is estimated using a production function approach with the exact specification varying

OG across countries depending on data availability. For most countries potential output is estimated using data on capital services, total factor productivity and potential employment which in part depends on estimates of the structural rate of unemployment (NAIRU). (Except for emerging countries, see note 11).

World Economic Outlook, IMF, April 2010

P.R. Lane and G.M. MilesiFerretti's Database, 2007

World Developpment Indicators, 2009

Chinn-Ito index, 2006

Percentage difference between actual GDP in constant prices, and estimated potential GDP
Economic Outlook, OECD, May 2010 


\begin{tabular}{|c|c|c|c|}
\hline Variable & Description & Unit & Source \\
\hline PG & $\begin{array}{l}\text { Annual population growth rate for year } t \text { is the } \\
\text { exponential rate of growth of midyear } \\
\text { population from year t- } 1 \text { to } t \text {, expressed as a } \\
\text { percentage. Population is based on the de facto } \\
\text { definition of population, which counts all } \\
\text { residents regardless of legal status or citizenship- } \\
\text {-except for refugees not permanently settled in } \\
\text { the country of asylum, which are generally } \\
\text { considered part of the population of the country } \\
\text { of origin. }\end{array}$ & Percent of total population & $\begin{array}{l}\text { World Developpment Indicators, } \\
2009\end{array}$ \\
\hline
\end{tabular}

Note: The independent variables are expressed relatively to their weighted world average in all regressions. The weights are the share in the world GDP in PPP terms (source: World Economic Outlook, IMF, April 2010). 


\section{Appendix 2}

Table A2.1: Determinants of the current account with Panel GMM for industrialized countries and emerging countries

\begin{tabular}{ccc}
\hline & $\begin{array}{c}\text { Panel GMM } \\
\text { (Industrialized Countries) }\end{array}$ & $\begin{array}{c}\text { Panel GMM } \\
\text { (Emerging Countries) }\end{array}$ \\
\hline \multirow{2}{*}{ CA(-1) } & $0.45^{* * *}$ & $0.13^{* *}$ \\
& $(0.03)$ & $(0.06)$ \\
RPG & $-2.55^{* * *}$ & $-2.08^{12 \%}$ \\
& $(0.53)$ & $(1.31)$ \\
ROG & $-0.61^{* * *}$ & $-0.19^{*}$ \\
& $(0.04)$ & $(0.10)$ \\
Significant time dummies & $0.84^{* * *}$ & $-0.81^{* * *}$ \\
& $(0.17)$ & $(0.21)$ \\
Number of Observations & $92-95,96-99,00-03$ & $96-99,00-03$ \\
& & 84 \\
J-statistic & 72 & 5.22 \\
& 11.95 & {$[0.81]$} \\
\hline
\end{tabular}

Notes: The independent and dependent variables are non-overlapping 4-year averages of the corresponding annual variables. Heteroskedasticity robust standard errors are reported in parentheses. The symbols $*,{ }^{* *}$, and $* * *$ indicate statistical significance at the 10 percent, 5 percent, and 1 percent levels, respectively. The last row show the J-statistic is the Sargan statistic for the validity of over-identifying restrictions. P-values are reported in square brackets. Source: author's estimates. 


\section{Appendix 3}

Table A3.1: Linear correlation between current account and relative financial openness for industrialized countries

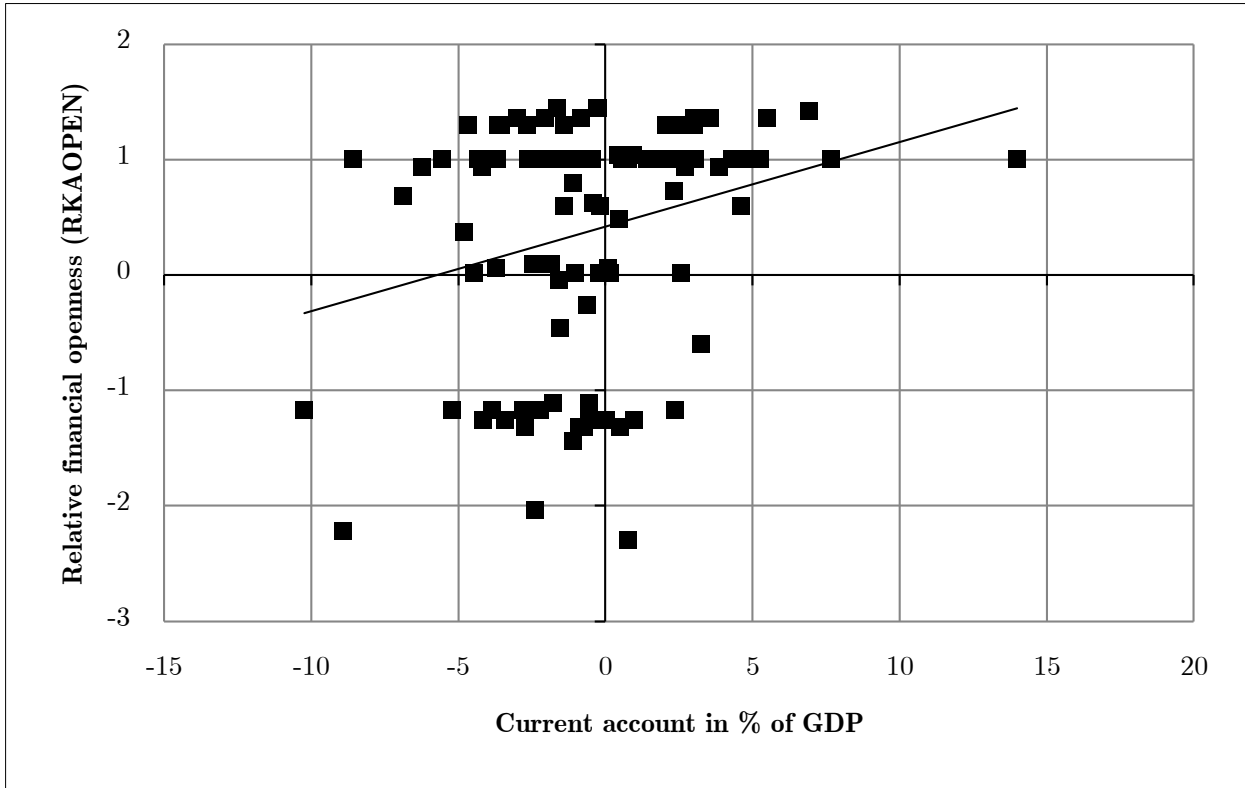

(Source: author's calculations)

Table A3.2: Linear correlation between current account and relative financial openness for emerging countries

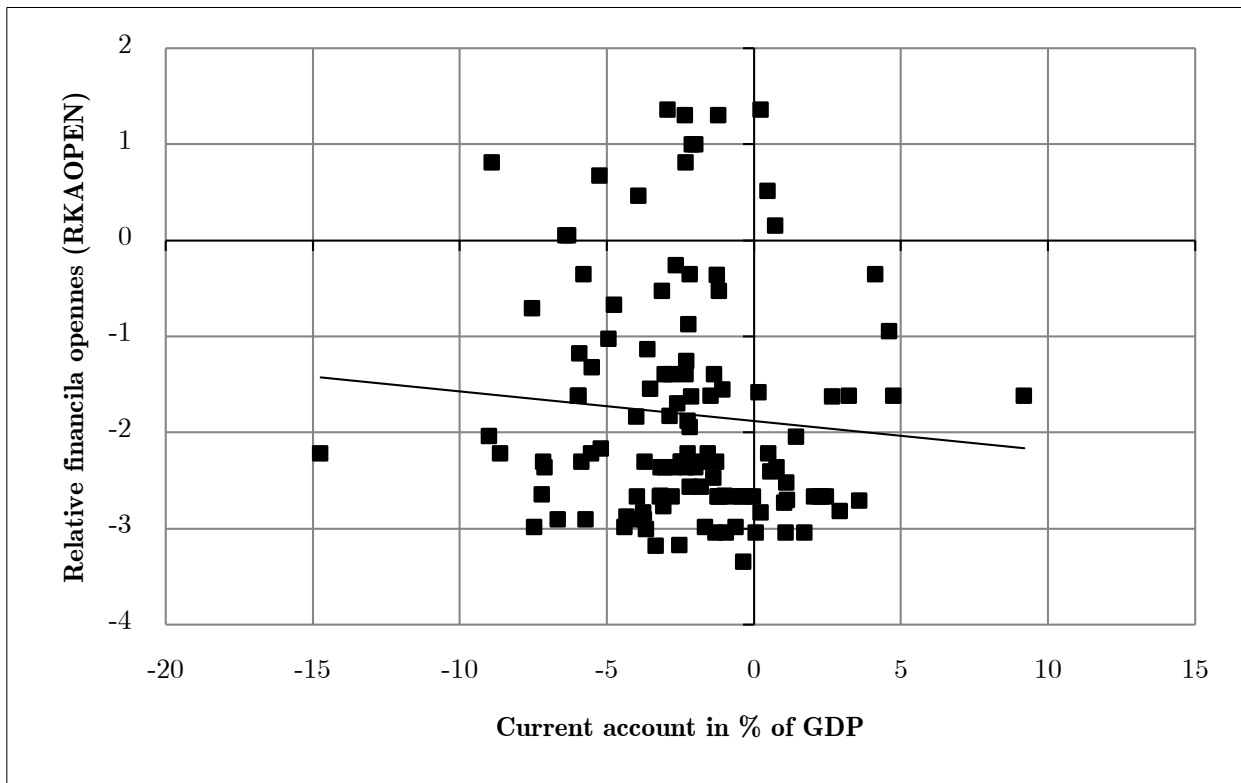

(Source: author's calculations) 


\section{Appendix 4}

Table A4.1: Determinants of the current account with a de facto measure of financial openness for industrialized countries

\begin{tabular}{ccc}
\hline & OLS Pooled & $\begin{array}{c}\text { OLS Individual } \\
\text { Fixed Effects }\end{array}$ \\
\hline \multirow{2}{*}{ Constant } & $-2.03^{* * *}$ & $-0.96^{* * *}$ \\
& $(0.13)$ & $(0.23)$ \\
\multirow{2}{*}{ RPG } & $-2.57^{* * *}$ & $-0.89^{* *}$ \\
& $(0.52)$ & $(0.39)$ \\
\multirow{2}{*}{$\Delta R G F A$} & $-0.56^{* *}$ & $-0.55^{* * *}$ \\
& $(0.17)$ & $(0.11)$ \\
Adjusted R squared & $0.01^{* * *}$ & $0.007^{* * *}$ \\
Number of Observations & $(0.00)$ & $(0.00)$ \\
\hline
\end{tabular}

Notes: The independent and dependent variables are non-overlapping 4-year averages of the corresponding annual variables. Heteroskedasticity robust standard errors are reported in parentheses. The symbols $*$, **, and *** indicate statistical significance at the 10 percent, 5 percent, and 1 percent levels, respectively. Source: author's estimates.

Table A4.2: Determinants of the current account with a de facto measure of financial openness for emerging countries

\begin{tabular}{|c|c|c|}
\hline & OLS Pooled & $\begin{array}{c}\text { OLS Individual } \\
\text { Fixed Effects }\end{array}$ \\
\hline \multirow{2}{*}{ Constant } & -0.67 & $-0.71^{* *}$ \\
\hline & $(0.48)$ & $(0.34)$ \\
\hline \multirow{2}{*}{$R P G$} & $-1.20^{* * *}$ & $-1.53^{* * *}$ \\
\hline & $(0.46)$ & $(0.38)$ \\
\hline \multirow{2}{*}{$R O G$} & $-0.43^{* * *}$ & $-0.34^{* * *}$ \\
\hline & $(0.11)$ & $(0.05)$ \\
\hline \multirow{2}{*}{$\triangle R G F A$} & $-0.02^{* *}$ & $-0.02^{* * *}$ \\
\hline & $(0.00)$ & $(0.00)$ \\
\hline Adjusted $R$ squared & 0.23 & 0.70 \\
\hline Number of Observations & 105 & 105 \\
\hline
\end{tabular}

Notes: The independent and dependent variables are non-overlapping 4-year averages of the corresponding annual variables. Heteroskedasticity robust standard errors are reported in parentheses. The symbols *, **, and *** indicate statistical significance at the 10 percent, 5 percent, and 1 percent levels, respectively. Source: author's estimates. 


\section{Appendix 5}

The KAOPEN index is a measure of financial openness (i.e. openness of the capital account). Introduced for the first time by Chinn and Ito in 2002, this index aims to measure the extensity of the capital controls (as it is an inverse measure of the intensity of capital controls) based on the information of the IMF's Annual Report on Exchange Rate Arrangements and Exchange Restrictions (AREAR).

The KAOPEN index is computed from binary dummy variables. These dummy variables are used to codify the restrictions on cross border financial transaction reported in the AREAR. Until 1996, the AREAR assign dummy variables for the four major categories on the restriction on the capital account (the existence of multiple exchange rates $\left(k_{1}\right)$, restrictions on current account transactions $\left(k_{2}\right)$, restrictions on capital account transactions $\left(k_{3}\right)$ and requirement of the surrender of export proceeds $\left(k_{4}\right)$ ). In order to understand the complexity of capital control policies, these four categories have been more disaggregated in 1996 (the variables indicating restrictions on current account transactions have been divided into thirteen categories).

Since they are focused on the effect of financial openness, Chinn and Ito reverse these binary variables. When variables are equal to zero, the capital account restrictions exist. In addition for the $k_{3}$ category, they used a five-year window where capital controls where not in effect $\left(\mathrm{SHAREk}_{3}\right)$.

$$
S H A R E k_{3, t}=\left(\frac{k_{3, t}+k_{3, t-1}+k_{3, t-2}+k_{3, t-3}+k_{3, t-4}}{5}\right)
$$

Then, they construct their index for capital account 'openness', which the first standardized principal component of $k_{1 t}, k_{2 t}, S H A R E k_{3 t}, k_{4 t}$ (Chinn and Ito, 2007). The more the country is open to cross-border capital flows, the more the KAOPEN index is high. This index has the merit to try to measure the intensity of capital restriction. The index was firstly designed to measure the extensity of capital controls, but as it incorporates various kinds of restrictions it may be a good proxy to gauge the intensity of capital account restrictions. Note that the $K A O P E N$ index is highly correlated with other measures of financial openness (Chinn and Ito, 2007). 
Figure A5.1: Relative KAOPEN for Industrialized Countries
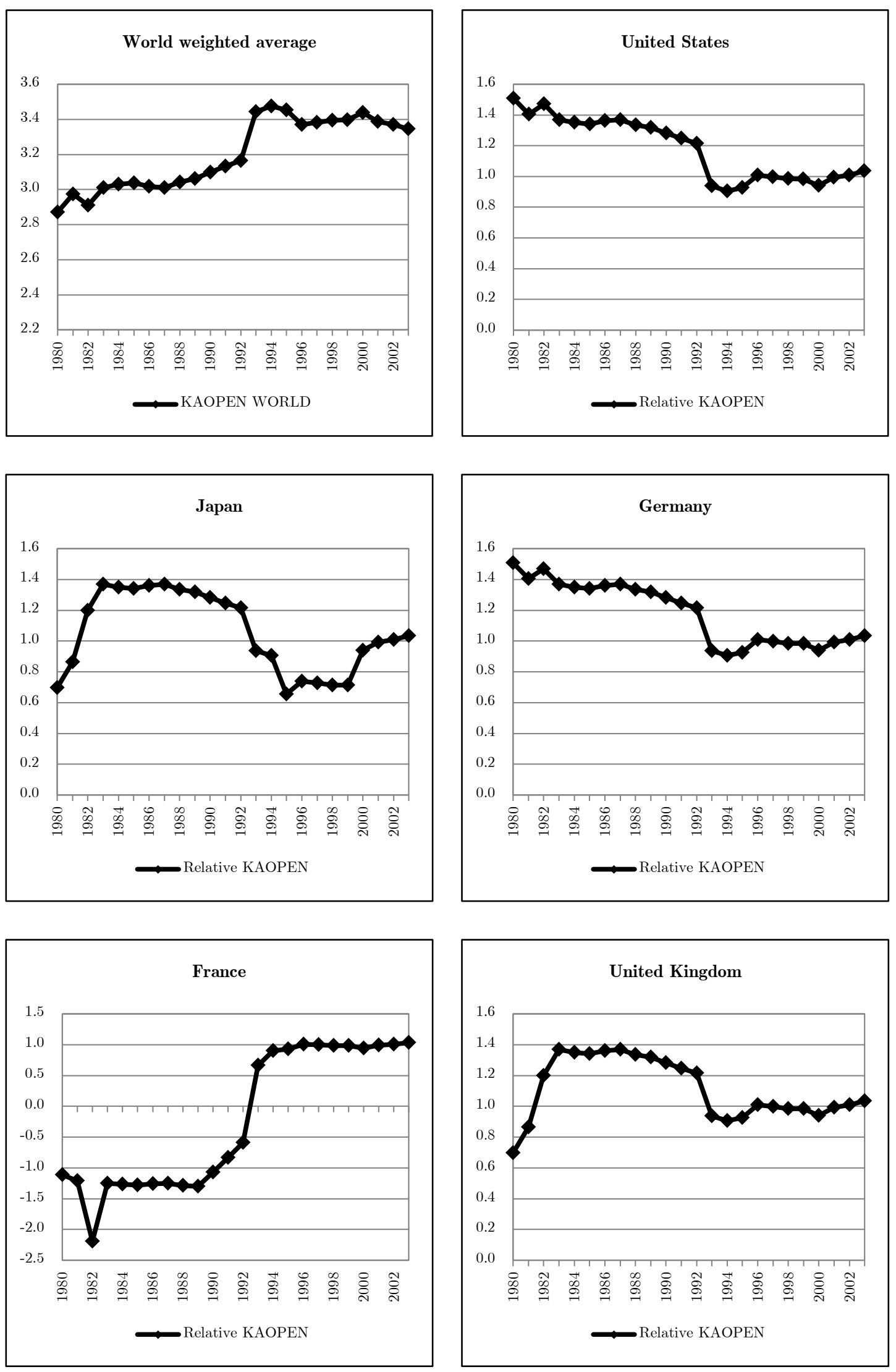

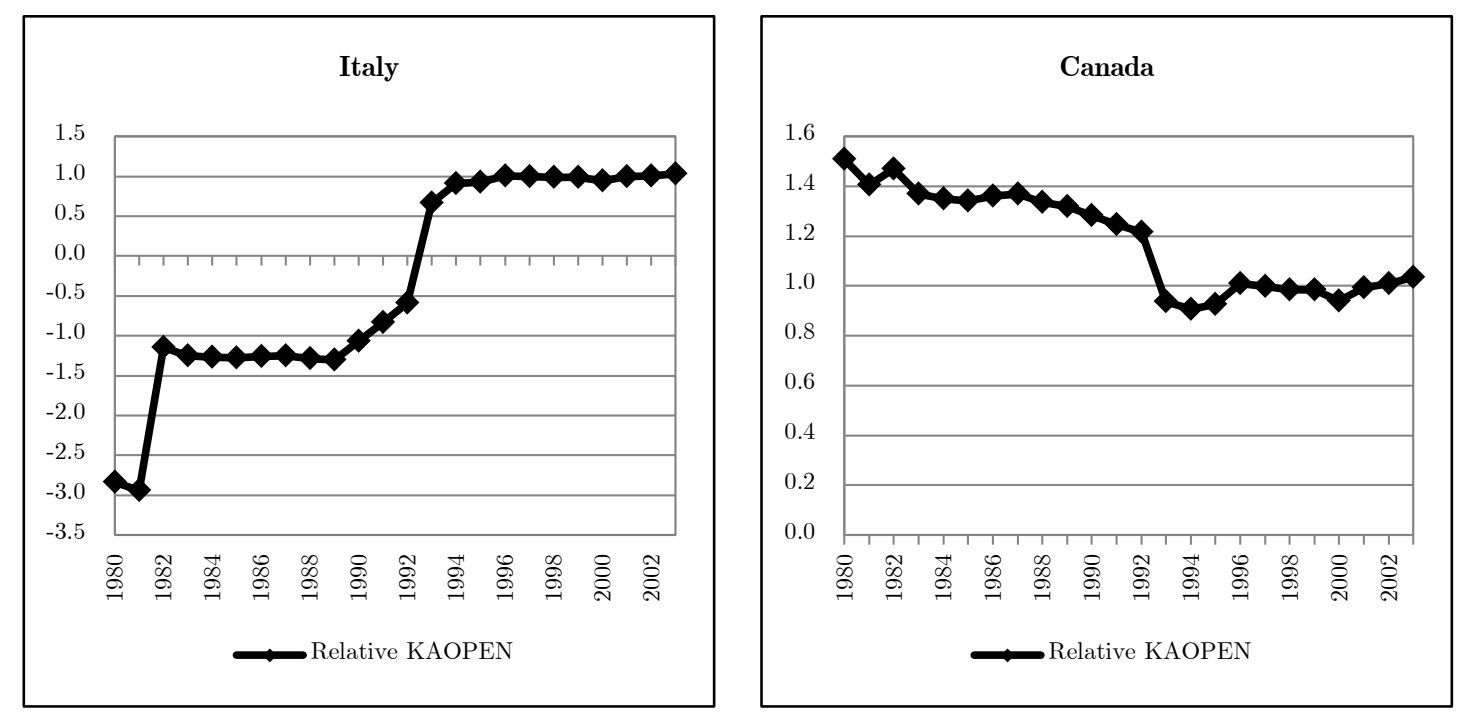

(Source: author's calculations)

For a number of industrialized countries (the United States, the United Kingdom, Canada, Germany, Japan), the RKAOPEN variable follows a negative trend since the beginning of the 1980's. The RKAOPEN variable describes the magnitude of capital openness relative to global average (which corresponds to a weighted average of the KAOPEN index (Chinn \& Ito, 2002, 2006). The weights are equal to the share of each country in world GDP in PPP terms. More precisely, RKAOPEN $=K A O P E N-\overline{K A O P E N})$.

Since the global average follows a positive trend since the mid-1980 and that many industrialized countries have already liberalized their capital account in early 1980's, the relative capital openness variable (RKAOPEN) dropped in these countries. These evolutions have contributed negatively to the current account since the estimated coefficient is positive and statistically significant for the industrialized countries' panel in all regressions. 
Figure A5.2: Relative KAOPEN for Emerging Countries
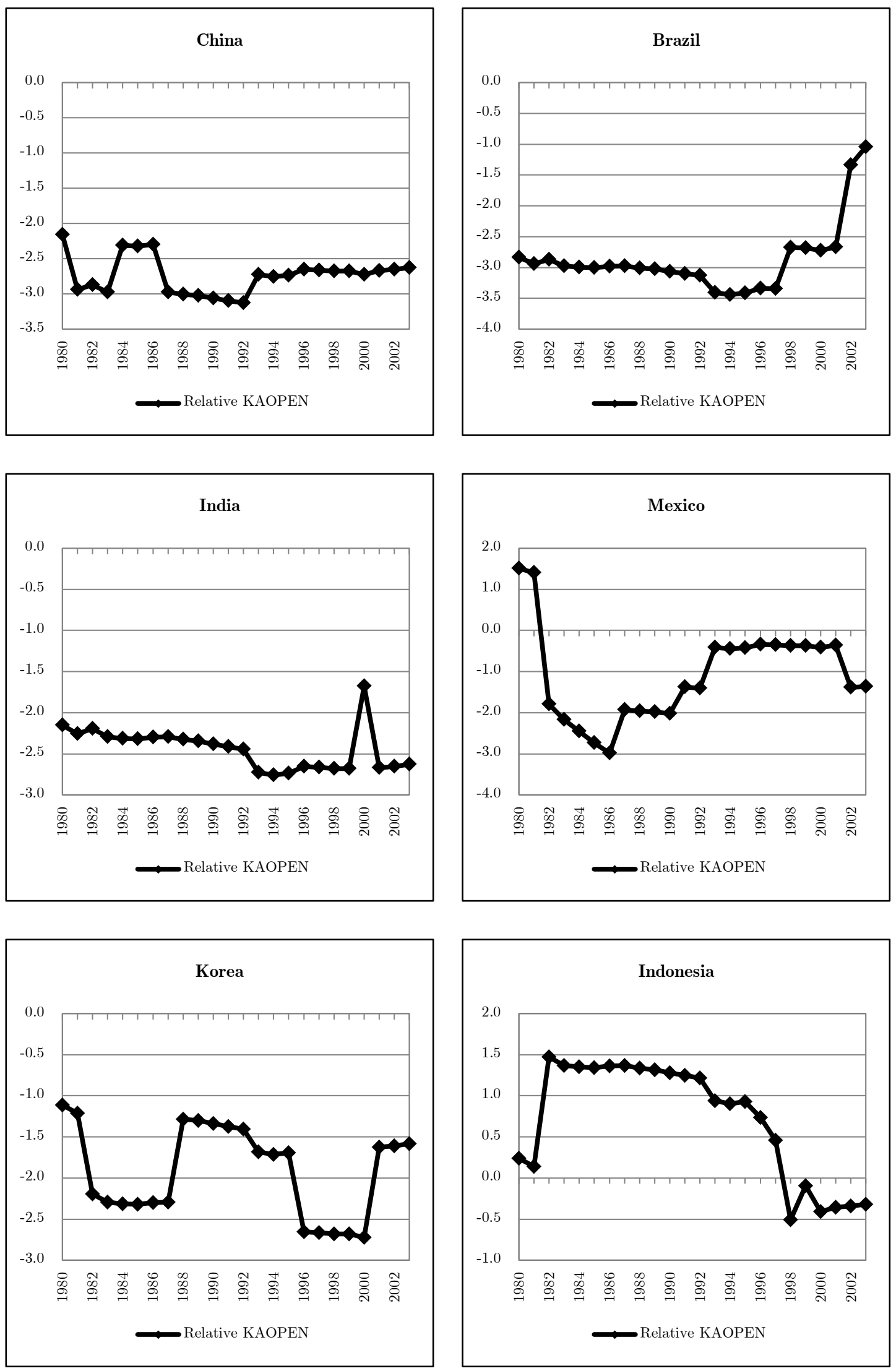

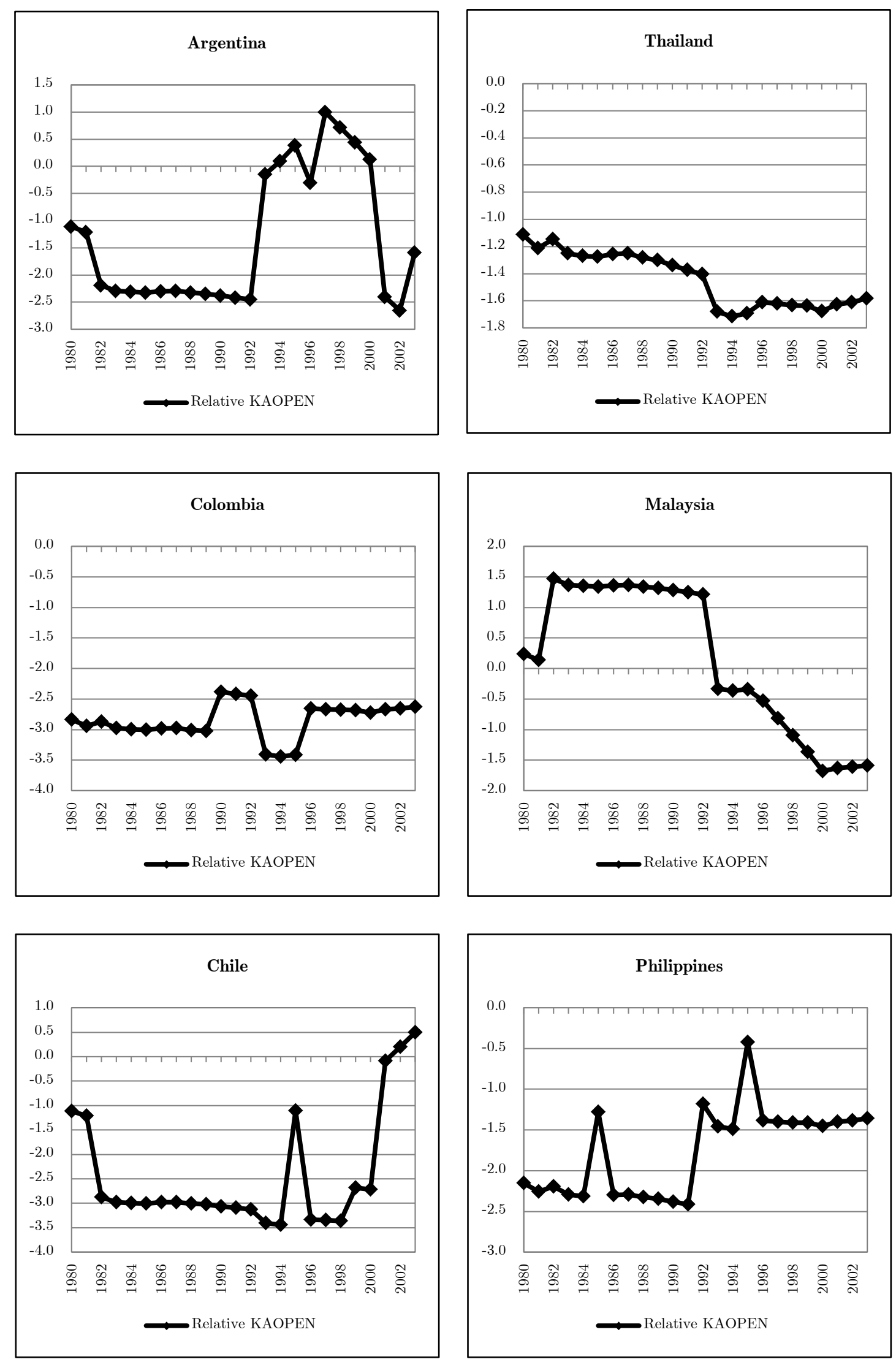

(Source: author's calculations) 
For a number of emerging countries (China, Malaysia, Thailand, Indonesia), the RKAOPEN variable follows a negative trend since the beginning of the 1980's. The RKAOPEN variable describes the magnitude of capital account openness relatively to global average (which corresponds to a weighted average of the KAOPEN index (Chinn \& Ito, 2002, 2006). The weights are equal to the share of each country in world GDP in PPP terms. More precisely, $R K A O P E N=K A O P E N-\overline{K A O P E N})$.

For these countries, the drop of the relative capital openness ( $R K A O P E N)$ variable means that they liberalized their capital account more slowly than the global average. These evolutions have contributed positively to the current account since the estimated coefficient is negative and statistically significant for the emerging countries' panel in all regressions. 


\section{References}

Arellano, M., Bond, S., 1991. Some Tests of Specification for Panel Data: Monte Carlo Evidence and an Application to Employment Equations, Review of Economic Studies, 58, pp. 277-297.

Arellano, M., Bover, O., 1995. Another Look at the Instrumental Variable Estimation of Error-Components Models, Journal of Econometrics, 68, pp. 29-51.

Baltagi, B.H., Demetriades, P.O., Law, S.H., 2009. Financial development and openness: Evidence from panel data, Journal of Development Economics, 89, pp. 285-296.

Bernanke, B., 2005. The Global Saving Glut and the U.S. Current Account. Remarks at the Sandridge Lecture, Virginia Association of Economics, Richmond, VA, March 10.

Carmignani, F., 2008. Does capital account liberalisation promote economic growth? Evidence from system estimation, Economics Bulletin, 6(49), pp. 1-13.

Chinn, M.D., 2010. Evidence on Financial Globalization and Crises: Global Imbalances, In: Encyclopedia of Financial Globalization (eds Caprio, G. et al.).

Chinn, M.D., Ito, H., 2002. Capital account liberalization, institutions and financial development: cross country evidence, Working Paper No. 8967, NBER.

Chinn, M.D., Ito, H., 2006. What matters for financial development? Capital controls, institutions, and interactions, Journal of Development Economics, 81, pp. 163-192.

Chinn, M.D., Ito, H., 2007. Current account balances, financial development and institutions: Assaying the world "saving glut", Journal of International Money and Finance, 26, pp. 546569.

Chinn, M.D., Ito, H., 2008. Global Current Account Imbalances: American Fiscal Policy versus East Asian Savings, Review of International Economics, 16, pp. 479-498.

Chinn, M.D., Ito, H., 2008. A New Measure of Financial Openness, Journal of Comparative Policy Analysis, 10, pp. 309-322. 
Chinn, M.D., Prasad, E.S., 2003. Medium term determinants of current accounts in industrial and develloping countries: an empirical exploration, Journal of International Economics, 59, pp. 47-76.

Clarida, R., 2005a. Japan, China, and the U.S. Current Account Deficit, CATO Journal 25, pp. 111-114.

Clarida, R., 2005b. Some Thoughts on 'The Sustainability and Adjustment of Global Current Account Imbalances'. Speech given at the Council on Foreign Relations, March 28.

Cline, W. R., 2010. Renminbi Undervaluation, China's Surplus, and the US Trade Deficit, Policy Brief 10-20, Peterson Institute for International Economics.

Dooley, M., Folkerts-Landau, D., Garber, P., 2003. An Essay on the Revived Bretton Woods System, NBER Working Paper 9971, NBER.

Dooley, M., Folkerts-Landau, D., Garber, P., 2008. Direct Investment, Rising Real Wages, and the Absorption of Excess Labor in the Periphery, in R. Clarida (Eds.), G-7 Current Account Imbalances: Sustainability and Adjustment, University of Chicago Press for NBER.

Eichengreen, B., 2001. Capital Account Liberalization: What Do Cross-Country Studies Tell Us?, World Bank Economic Review, 15, pp. 341-365.

Faruqee, H., Isard, P. (Eds), 1998. Exchange rate assessment: Extensions to the macroeconomic balance approach, IMF Occasional Paper 167, International Monetary Fund.

Ito, H., Chinn, M.D., 2007. East Asia and Global Imbalances: Saving, Investment, and Financial Development, NBER Working Paper 13364, NBER.

Jeong, S.-E., Mazier, J., 2003. Exchange rate regimes and equilibrium exchange rates in East Asia, Revue économique, 54, pp. 1161-1182.

Jeong, S.-E., Mazier, J., Saadaoui, J., 2010. Exchange rate misalignments at world and European level: a FEER approach, Économie Internationale / International Economics, 121, pp. 25-58.

Kose, M.A., Prasad, E., Rogoff, K., Wei, S. J., 2006. Financial Globalization: A Reappraisal. NBER Working Paper No. 12484, NBER. 
Lee, J., Milesi-Ferreti, G.M., Ostry, J.D., Prati, A., Ricci, L.A., 2008. Exchange rate assessments: CGER methodologies, IMF Occasional Papers 261, International Monetary Fund.

Quinn, D.P., Toyoda, A.M., 2008. Does Capital Account Liberalization Lead to Growth?, Review of Financial Studies, 21(3), pp. 1403-1449.

Servén, L., Nguyen, H., 2010. Global Imbalances Before and After the Global Crisis, Policy Research Working Paper 5354, The World Bank.

The Economist, 'Finally, a talking-shop worth having', November 4, 2010. 